\title{
GLASBENO IZOBRAŽEVANJE V LJUBLJANSKIH ŠOLAH V DRUGI POLOVICI 16. IN NA ZAČETKU 17. STOLETJA
}

\author{
KLEMEN GRABNAR \\ Znanstvenoraziskovalni center SAZU
}

Izvleček: V prispevkuje predstavljeno glasbeno delo v štirih ključnih izobraževalnih ustanovah v Ljubljani včasu med 1550 in 1630: v protestantski nemški šoli, stanovski latinski šoli, stolni šoli pri sv. Nikolaju in v jezuitskem kolegiju, omenjena pa je tudi glasbenopedagoška dejavnost $v$ šoli samostana nemškega viteškega reda.

Ključne besede: glasbeno izobraževanje, zgodovina šolstva, zgodovina Ljubljane, reformacija in protireformacija na Slovenskem

\begin{abstract}
The contribution presents the musical activities which took place in the four main educational institutions in Ljubljana: the Protestant German school, the Latin school, the Cathedral school of St. Nicholas, and the Jesuit college, covering the period from ca. 1550 to ca. 1630. Also mentioned are the musical activities at the school at the monastery of the Teutonic order in Ljubljana.
\end{abstract}

Keywords: music education, history of education, history of Ljubljana, Reformation and Counter-Reformation in Slovenia

Raziskovanje pridobivanja glasbenih znanj v preteklosti je bilo v muzikologiji do nedavnega potisnjeno na rob. To pomeni, da so bila opažanja v zvezi z glasbenim izobraževanjem pogosto del razprav, usmerjenih v druga področja raziskav glasbene preteklosti. V slovenskem prostoru so to predvsem zgodovinski pregledi delovanja posameznih institucij, pa tudi splošne glasbene zgodovine. ${ }^{1} \mathrm{~V}$ zadnjem času je viden porast študij,

1 Med slednje sodijo naslednja temeljna glasbenozgodovinska dela: Dragotin Cvetko, Zgodovina glasbene umetnosti na Slovenskem, 3 zv., Ljubljana, Državna založba Slovenije, 1958-1960; Dragotin Cvetko, Slovenska glasba v evropskem prostoru, Ljubljana, Slovenska matica, 1991; Janez Höfler, Tokovi glasbene kulture na Slovenskem od začetkov do 19. stoletja, Ljubljana, Mladinska knjiga, 1970. Za obravnavano obdobje pa sta pomembni predvsem deli: Janez Höfler, Glasbena umetnost pozne renesanse in baroka na Slovenskem, Ljubljana, Partizanska knjiga, 1978; Andrej Rijavec, Glasbeno delo na Slovenskem v obdobju protestantizma, Ljubljana, Slovenska matica, 1967. Glasbenega izobraževanja se dotikajo tudi nekateri splošni pregledi šolstva na Slovenskem; med temi sta najvidnejša Jože Ciperle in Andrej Vovko, Šolstvo na Slovenskem skozi stoletja, Ljubljana, Slovenski šolski muzej, 1987; Vlado Schmidt, Zgodovina šolstva in pedagogike na Slovenskem, 3 zv., Ljubljana, Delavska enotnost, 1988. Temeljno 
ki se ukvarjajo z različnimi vidiki glasbene pedagogike v preteklosti. Recentni pregled najnovejših dognanj je bil nedavno predstavljen na mednarodni konferenci Reading and Writing the Pedagogy of the Renaissance: Students, Teachers, and Materials of Musical Learning, 1470-1650, ki je potekala na konservatoriju Peabody Univerze Johna Hopkinsa v Baltimorju (Maryland) v Združenih državah Amerike. ${ }^{2}$

Obravnavana tematika je deležna vse večje pozornosti tudi med slovenskimi muzikologi. ${ }^{3}$ Kljub temu, da je o pridobivanju glasbene izobrazbe v drugi polovici 16 . in na začetku 17. stoletja znanih kar nekaj drobcev, ki pričajo o prisotnosti glasbenega poučevanja na Slovenskem, pa sistematična sinteza do sedaj še ni bila opravljena. Pričujoči prispevek tako skuša strniti vedenje o glasbenem izobraževanju v drugi polovici 16. in na začetku 17. stoletja na slovenskih tleh ter tako zapolniti vrzel v poznavanju tega za glasbeno kulturo in zgodovino glasbene pedagogike pomembnega področja.

Glasbeno izobraževanje je v drugi polovici 16. in na začetku 17. stoletja potekalo v različnih okvirih, ki so bili bolj ali manj organizirani, od možnega samouštva pa do izobraževanja pod privatnim ali institucionalnim okriljem. Spričo pomanjkljivih podatkov je o samouštvu in privatnem izobraževanju težko reči kaj določnejšega, nekoliko več pa je s pomočjo ohranjenega gradiva mogoče razbrati o glasbenopedagoškem delovanju v različnih ustanovah. Osnovni nosilci glasbenoizobraževalnega dela so bile šole, ki so bile pred 18. stoletjem praviloma vse tesno povezane $\mathrm{z}$ delovanjem cerkvenih ustanov. Najvidnejšo vlogo v Ljubljani so imele v tem času tri vzgojno-izobraževalne ustanove: stanovska šola, stolna šola pri sv. Nikolaju in jezuitski kolegij. Poleg treh navedenih pa sta v Ljubljani delovali še protestantska nemška šola in šola samostana nemškega viteškega reda.

V sredini 16. stoletja so začele najvidnejšo vlogo v šolstvu prevzemati protestantske šole. V Ljubljani je izpričan obstoj mestne (nemške) šole in stanovske (latinske) šole, za

delo o splošnem šolstvu v času protestantizma pa predstavlja Vlado Schmidt, Pedagoško delo protestantov na Slovenskem v XVI. stoletju, Ljubljana, Državna založba Slovenije, 1952; podobno tematiko obravnava tudi Tadej Vidmar, »Obena deshela, ne meisto ne gmaina, ne mogo pres shul« - Usoda protestantskih deželnih šol v Ljubljani, Celovcu in Gradcu, Šolska kronika 9 (33)/1 (2000), str. 9-27. Nekoliko bolje raziskano je glasbeno šolstvo od 19. stoletja dalje: Cvetko Budkovič, Razvoj glasbenega šolstva na Slovenskem, 2 zv., Ljubljana, Znanstveni inštitut Filozofske fakultete, 1992 in 1995.

2 Sad omenjene konference je med drugim monografija Music Education in the Middle Ages and the Renaissance, ur. Russell E. Murray, Susan Forscher Weiss in Cynthia J. Cyrus, Bloomington in Indianapolis, Indiana University Press, 2010.

3 Za obravnavano obdobje je relevantna predvsem študija Metoda Kokole, Musicale essercitio. O glasbenem izobraževanju slovenskih protestantov, Vera in hotenja. Študije o Primožu Trubarju in njegovem času, ur. Sašo Jerše, Ljubljana, Slovenska matica, 2009, str. 162-183. Med najnovejše razprave pa sodijo: Metoda Kokole, Glasbenoteoretični in pedagoški priročniki iz »dolgega« 18. stoletja na Slovenskem, Muzikološki zbornik 47/1 (2011), str. 49-74; Radovan Škrjanc, Relativnost in funkcija zgodovinopisnega interpretiranja glasbe - predstavitev problema na primeru zgodovinske analize novomeških Fundamenta, Muzikološki zbornik 47/1 (2011), str. 75-91; Katarina Šter, »Mojster ima veliko mujo, inu poterpeshlivost«: rokopisni učbenik o osnovah glasbene teorije in koralnem petju iz Pokrajinskega arhiva Koper, Muzikološki zbornik 47/1 (2011), str. 93-111. Avtorji se v navedenih razpravah posvečajo predvsem glasbenodidaktičnim virom iz druge polovice 17. stoletja, 18. stoletja in začetka 19. stoletja, ohranjenim v slovenskih knjižnicah in arhivih. 
kateri je bolj ali manj znano glasbeno delovanje. Nemška šola je pripadala kategoriji nižjega šolstva, kjer so se poučevali elementarni predmeti. Predmetnik je na tovrstnih šolah vključeval tudi glasbeni pouk - v Ljubljani je obsegal petje enoglasnih protestantskih pesmi v slovenščini in nemščini.

Učenje pesmi je v nemški šoli potekalo tako, da so učenci, dokler niso pesmi popolnoma osvojili, ponavljali za učiteljem. ${ }^{4}$ Iz tega je mogoče sklepati, da - vsaj učenci - pesmaric pri pouku niso uporabljali. ${ }^{5}$ Glavni namen pevskega pouka je bila poleg posredovanja verskega znanja in zavesti priprava učencev za petje pri bogoslužju v osrednji protestantski cerkvi na Slovenskem, tj. v špitalski cerkvi sv. Elizabete v Ljubljani. Do ustanovitve stanovske šole leta 1563 je bil šolski zbor nemške šole edino glasbenoizvajalsko telo v cerkvi (če izvzamemo petje ljudstva), kar pomeni, da se je repertoar pesmi, ki so se ga učenci učili pri pouku, najverjetneje prilagajal vsakokratni liturgični vsebini bogoslužja, pri katerem so sodelovali. ${ }^{6}$ Učenci so s petjem sodelovali tudi pri pogrebih.

Od ustanovitve stanovske šole do leta 1582, ko je njeno delovanje reorganizirano, so gojenci obeh šol pri bogoslužju skupaj sodelovali s petjem enoglasnih protestantskih pesmi v slovenskem in nemškem jeziku, nato pa so bile naloge razmejene tako, da naj bi učenci nemške šole pod vodstvom svojega kantorja prevzeli enoglasno petje v slovenskem jeziku in petje pri pogrebih, dijaki stanovske šole pa enoglasno petje v nemškem jeziku in večglasno petje.

Med imeni učiteljev nemške šole v Ljubljani se v povezavi z glasbo kot najpomembnejša pojavljajo sledeča imena: Jakob Kaltenbrunner, ki je poleg poučevanja v letih 1565-1573 v cerkvi vodil koralno petje v slovenskem in nemškem jeziku, Werner Feurer, učitelj v letih 1573-1579 in cerkveni vodja tako koralnega kot večglasnega petja, ter Matija Vinizianer, ki je poučeval v letih 1575-1598 in med drugim vodil tudi koralno petje v slovenskem jeziku.

Število učencev na šoli je nihalo, kar je moglo vplivati na delo pri pouku ter na raven njihovega petja v cerkvi. ${ }^{7}$ Socialni položaj učencev je bil raznolik; znano je, da so se morali revnejši učenci preživljati tudi s petjem na mestnih ulicah. Šola je obstajala do leta 1598, ko je bil protestantizem uradno prepovedan in ko so bili posledično iz Ljubljane izgnani protestantski pridigarji in učitelji. Kaže pa, da je protestantska šolska dejavnost potekala tudi še po omenjenem letu, saj so za leto 1599 ohranjeni podatki o prepevanju

4 A. Rijavec, nav. delo, str. 60-61 in 94.

5 Prvi tiski z notnimi zapisi so se na Slovenskem pojavili v drugi polovici 16. stoletja. Najstarejši je Catechismus Primoža Trubarja iz leta 1550, ki mu je sledilo še sedem protestantskih glasbenih tiskov. Gl. Edo Škulj, Protestantski napevi, Cerkveni ljudski napevi I, Ljubljana, Družina, 2000; Zbrana dela Primoža Trubarja 4, ur. Jonatan Vinkler, Ljubljana, Rokus, Slovensko protestantsko društvo Primož Trubar, 2006.

${ }^{6}$ O petju slovenskih protestantskih pesmi pri bogoslužju slovenske reformirane cerkve piše Jurij Snoj, Dalmatinova pesmarica in slovensko reformirano bogoslužje, Reformacija na Slovenskem (ob 500-letnici Trubarjevega rojstva), ur. Aleksander Bjelčevič, Obdobja 27, Ljubljana, Znanstvena založba Filozofske fakultete, 2010, str. 483-504.

7 Posebej pomenljivo v tej zvezi je poročilo šolskih nadzornikov iz leta 1575, v katerem omenjajo šibko petje maloštevilnih učencev v cerkvi pod vodstvom kantorja Feurerja. A. Rijavec, nav. delo, str. 179, op. 303. 
protestantskih pesmi pri pogrebu, na katerem so pod vodstvom učitelja sodelovali učenci nemške šole. ${ }^{8}$

Največ podatkov v zvezi z glasbenim izobraževanjem je ohranjenih za stanovsko šolo, ki je pripadala kategoriji srednjega šolstva in je imela v drugi polovici 16. stoletja $\mathrm{v}$ Ljubljani najvidnejšo vlogo. ${ }^{9}$ Leta 1563 so jo ustanovili kranjski deželni stanovi, delovala pa je vse do leta 1598, ko jo je zadela enaka usoda kot nemško. V stanovski šoli so učenci pridobivali splošna znanja, pri čemer je bila v ospredju latinščina. Na začetku obstoja šole so učenci dobivali verjetno predvsem osnovna znanja iz trivija, kasneje pa so s pridobljenim znanjem imeli tudi možnost morebitnega nadaljnjega izobraževanja na univerzah. Pomembno mesto je imela tudi glasba, kar je razvidno predvsem iz ohranjenih šolskih redov, pa tudi drugih dokumentov.

V času obstoja šole se je v njenih vrstah zvrstilo kar nekaj rektorjev (tj. predstojnikov), kantorjev, učiteljev in pomožnih učiteljev. Njihova vloga v izobraževalnem procesu ni vedno jasna, in to velja še posebno za glasbeni pouk. Prvi rektor (tj. predstojnik) in hkrati edini učitelj je bil Lenart Budina (rektor v obdobju 1563-1566), ki je v Ljubljani že dalj časa zasebno poučeval. ${ }^{10}$ Za njim so se na čelu šole zvrstili še štirje rektorji: Adam Bohorič (1566-1582 in 1595-1598), Nikodem Frischlin (1582-1584), Jakob Praentelius (1585-1595) in Engelbert Engel (1598). ${ }^{11}$ Največ znanega je iz obdobja rektorjev Bohoriča (v prvem obdobju) in Frischlina. Iz njunega časa sta se ohranila dva učna reda stanovske šole. ${ }^{12}$

Bohoričev šolski red je drugi red ljubljanske stanovske šole po vrsti (prvi, prav tako izpod njegovega peresa, se ni ohranil); veljal je od leta 1575 do leta 1584 . Po njegovih določilih se je glasbeni pouk pričel izvajati v tretjem razredu in je potekal še v četrtem razredu, in sicer štiri dni v tednu (v ponedeljek, torek, četrtek in petek) po eno uro (od dvanajste do prve ure). Glasbeno bolj vešči učenci, zbrani v zbor, ki je izvajal večglasno glasbo, pa so poleg tega imeli še dve dodatni vaji na teden, navadno ob sredah in sobotah popoldne, po drugih šolskih obveznostih.

8 A. Rijavec, nav. delo, str. 94-96.

9 Delovanje stanovske šole na področju glasbe je temeljito opisal A. Rijavec, nav. delo, str. 57-94.

${ }^{10}$ Lenart Budina je bil v šolstvu že izkušen, bil pa naj bi tudi dobro glasbeno izobražen. Primož Simoniti, Humanizem na Slovenskem in slovenski humanisti do srede XVI. stoletja, Ljubljana, Slovenska matica, 1979, str. 114-118. Domneva se, da je bil Budina na šoli tudi kantor, saj izvira prva omemba šolskega kantorja šele iz leta 1570. M. Kokole, Musicale essercitio. O glasbenem izobraževanju slovenskih protestantov, str. 164, op. 12. Dokler šola ni pridobila prostorov, je šolanje potekalo kar na Budinovem domu.

${ }^{11}$ Več o rektorjih v delu: Theodor Elze, Die Rectoren der Krainischen Landschaftsschule in Laibach während des XVI. Jahrhunderts, Jahrbuch der Gesellschaft für die Geschichte des Protestantismus in Oesterreich 20 (1899), str. 117-153.

12 Besedili obeh redov sta skupaj s slovenskim prevodom objavljeni v V. Schmidt, Pedagoško delo protestantov na Slovenskem v XVI. stoletju, str. 39-58, 88-113, 189-201 in 203-224. Z glasbenega stališča sta obširneje komentirana v D. Cvetko, Zgodovina glasbene umetnosti na Slovenskem I, str. 113-118; A. Rijavec, nav. delo, str. 64-84; A. Rijavec, Glasba v šolskih redih ljubljanske protestantske stanovske šole, Muzikološki zbornik 1 (1965), str. 9-21; A. Rijavec, Glasbena vzgoja v 16. stoletju - ob primeru šolskih redov ljubljanske protestantske stanovske šole, Gallus Carniolus in evropska renesansa 2, ur. Dragotin Cvetko in Danilo Pokorn, Ljubljana, Slovenska akademija znanosti in umetnosti, 1992, str. 185-192. 
V Frischlinovem šolskem redu (tretji po vrsti, v veljavi od leta 1582 dalje) je bilo glasbi, še posebej večglasni, namenjeno še več pozornosti. Pouk glasbe se je kot neobvezni predmet pričel že v prvem razredu, obvezen pa je bil v razredih od drugega do petega, v enakih terminih in ob enakih urah, kot to določa Bohoričev red. Frischlinov red predpisuje prav tako dodatne vaje za izvajanje večglasnega repertoarja, pri čemer v soboto in pred prazniki na vajah predvideva tudi sodelovanje organista in mestnih glasbenikov.

Glavni namen glasbenega izobraževanja na stanovski šoli je bil, tako kot na nemški šoli, priprava učencev za petje v cerkvi sv. Elizabete. ${ }^{13}$ Poudarek je bil na pevskem pouku (petje enoglasnih protestantskih pesmi v slovenščini in nemščini ter petje večglasnih kompozicij), učenci pa so se spoznali tudi z osnovnimi glasbenoteoretičnimi elementi. Za glasbeni pouk sta bila predpisana takrat zelo razširjena priročnika Heinricha Fabra, Compendiolum musicae (Brunswick, 1548) in Ad musicam practicam introductio (Nürnberg, 1550). ${ }^{14}$ Učence je pri skupnem pouku poučeval kantor s pomočjo svojih pomočnikov.

Kantorji, ki so jih vzdrževali deželni stanovi in so bili po svojem dohodku in ugledu takoj za rektorjem, so bili Werner Feurer (kantor v letih 1569-1579), Sebastian Semnizer (1579-1584), Hand Döller (1585-1588), Wolfgang Striccius (1588-1592) in Sebastian Poppius (1592-1598). V prvih letih delovanja pa je nalogo kantorja opravljal kar rektor sam. Med kantorji izstopata Semnizer in Striccius, ki sta bila tudi skladatelja. Prvi je kot skladatelj le omenjen in njegovih kompozicij ne poznamo, tiskane zbirke drugega pa so se ohranile. ${ }^{15}$ Stricciusove skladbe tako predstavljajo primer repertoarja, ki bi ga mogli učenci stanovske šole dejansko izvajati. ${ }^{16}$

Omeniti velja še učitelja Casparja Gasteliusa (na stanovski šoli v letih 1574-1575), ki je kasneje deloval na graški protestantski gimnaziji. Mesto pomočnikov pa je bilo precej nestalno, saj so se na tem mestu zvrstila mnoga imena. Število učencev je že kmalu po začetnih letih delovanja šole strmo naraslo in kasneje nekoliko nihalo. Vzrok za odhod

${ }^{13}$ O petju učencev pri bogoslužju govori že Primož Trubar v Cerkovni ordningi (1564); Zbrana dela Primoža Trubarja 3, ur. Jonatan Vinkler, Ljubljana, Rokus, Slovensko protestantsko društvo Primož Trubar, 2005, str. 227-578.

${ }^{14}$ Tovrstne publikacije so bile namenjene predvsem učiteljem. M. Kokole, Musicale essercitio. O glasbenem izobraževanju slovenskih protestantov, str. 171; James Haar, Lessons in Theory from a Sixteenth-Century Composer, Altro Polo. Essays on Italian Music in the Cinquecento, ur. Richard Charteris, Sydney, University of Sydney, 1990, str. 51-81.

${ }^{15}$ Več o Stricciusu in njegovi glasbi v delih: Jože Sivec, Kompozicijski stavek Wolfganga Stricciusa, Razprave 7/3, Ljubljana, SAZU, 1972; Jože Sivec, Wolfgang Striccius und sein Beitrag zur Musik der Reformation in Slowenien, Ein Leben zwischen Laibach und Tübingen. Primus Truber und seine Zeit. Intentionen, Verlauf und Folgen der Reformation in Württemberg und Innerösterreich, ur. Rolf-Dieter Kluge, München, O. Sagner, 1995, str. 235-250.

${ }^{16}$ G1. Wolfgang Striccius, Neue teutsche Lieder (1588), Der erste Theil newer teutscher Gesänge (1593), ur. Jože Sivec, Monumenta artis musicae Sloveniae XXXII, Ljubljana, SAZU, ZRC SAZU, Muzikološki inštitut, 1997. 
učencev s šole je bila navadno revščina. ${ }^{17}$ Iz prikaza je razvidno, da je bila organizacija glasbenega dela na stanovski šoli v Ljubljani tako primerljiva z nemškimi deželami. ${ }^{18}$

Po zatonu protestantizma je začel ponovno rasti pomen katoliških izobraževalnih ustanov. Večjo veljavo je po ukinitvi stanovske šole ponovno pridobila stolna šola pri sv. Nikolaju s sicer že več stoletno tradicijo. ${ }^{19} \mathrm{~V}$ drugi polovici 16 . stoletja in na začetku 17. stoletja je šola svojim učencem nudila znanje, potrebno za vpis na izobraževalno ustanovo višjega tipa. Učenci, ki so se nadalje izobraževali, so pogosto postali gojenci jezuitske gimnazije v Gradcu, v 17. stoletju pa tudi ljubljanskega jezuitskega kolegija. Mnogi izmed njih so se posvetili duhovniškemu poklicu.

Glavni namen glasbenega pouka na šoli sv. Nikolaja je bil usmerjen v usposabljanje učencev za petje pri bogoslužju v ljubljanski stolni cerkvi sv. Nikolaja. Za ugotavljanje glasbene dejavnosti učencev stolne šole so pomembni zlasti zapisi o beneficijih - ustanovah dobrotnikov, ki so cerkvi zapustili določeno premoženje, iz katerega se je financiralo opravljanje točno določenih nalog, kot so razne molitve, opravljanje maš ipd. V tovrstnih zapisih so pogosto navedena določila, ki se nanašajo na glasbo v cerkvenem obredju.

Glasbene obveznosti, navedene v določilih, so v nekaterih primerih precej obsežne. V drugi polovici 16. stoletja so se opravljale npr. obveznosti, določene za officium sabbatinum, ki ga je leta 1449 pri oltarju Matere božje ustanovil pičenski škof Martin. Ta je učencem šole sv. Nikolaja pod vodstvom učitelja nalagal petje speva Salve Regina pri Marijinem oltarju vsako soboto zvečer in v postnem času vsak večer. Z glasbenega stališča sta še bolj zanimiva leta 1435 ustanovljeni beneficij sv. Jurija Primoža Vička in leta 1463 ustanovljeni beneficij ustanovitelja in dobrotnika ljubljanske škofije cesarja Friderika. Prvi je učencem pod učiteljevim vodstvom nalagal vsakodnevno petje pri mašnem bogoslužju pri oltarju sv. Jurija, drugi pa vsakodnevno peto jutranjo in dopoldansko mašo pri velikem oltarju. ${ }^{20}$

V času protestantizma se je opravljanje obveznosti, izhajajočih iz tovrstnih ustanov, zanemarjalo. Prav tako je domnevno nazadovalo tudi delo stolne šole. ${ }^{21} \mathrm{Kaže}$, da so razmere postale bolj ugodne s prihodom škofa Janeza Tavčarja (škof v letih 1580-1597), ko se v virih poleg učitelja pojavlja še njegov pomočnik. Pogoji so se še izboljšali v času škofa

${ }^{17}$ Revni učenci so bili pogosto glasbeno dejavni tudi izven šole in cerkve ter so se na tak način preživljali. A. Rijavec, Glasbeno delo na Slovenskem v obdobju protestantizma, str. 73-74.

${ }^{18}$ Prim. Karl Heinrich Ehrenforth, Geschichte der musikalischen Bildung. Eine Kultur-, Sozialund Ideengeschichte in 40 Stationen, von den antiken Hochkulturen bis zur Gegenwart, Mainz, Schott, 2005, str. 214-221.

${ }^{19}$ Josip Gruden, Cerkvene razmere med Slovenci v 15. stoletju in ustanovitev ljubljanske škofije, Ljubljana, Leonova družba, 1908, str. 108; Josip Gruden, Šola pri sv. Nikolaju in ljubljansko nižje šolstvo po reformacijski dobi, Carniola 6 (1915), str. 1-2.

${ }^{20}$ Opravljanje določil slednjega se pojavlja v šolskem redu stolne šole še v drugi polovici 17. stoletja. Besedilo tega reda iz leta 1679 je objavljeno v delu: J. Gruden, Šola pri sv. Nikolaju in ljubljansko nižje šolstvo po reformacijski dobi, str. 19-21. A. Rijavec, Glasbeno delo na Slovenskem vobdobju protestantizma , str. 13-16. Beneficijem se je v posebnem prispevku posvetil tudi Janez Höfler, Glasba v poznosrednjeveških beneficijih na Slovenskem, Srednjeveška glasba na Slovenskem in njene evropske vzporednice, ur. Jurij Snoj, Ljubljana, ZRC SAZU, Založba ZRC, 1998, str. 85-94.

${ }^{21}$ A. Rijavec, Glasbeno delo na Slovenskem v obdobju protestantizma, str. 20-22. 
Tomaža Hrena (škof v letih 1597-1630). ${ }^{22}$ Zaradi zaprtja protestantskih šol je bila med izobraževalnimi ustanovami manjša konkurenca, poleg tega je mestni magistrat ponovno pričel denarno podpirati stolno šolo. Učitelji so bili tako plačani iz več virov, poleg podpore mesta in seveda cerkve so bili njihovi viri dohodka tudi šolnina in morebitni darovi. Zdi se, da finančni položaj učiteljev, ki so med drugim skrbeli tudi za deške pevce, kljub temu ni mogel biti ugoden, saj so se ohranile mnoge njihove prošnje za dodatno denarno pomoč. ${ }^{23}$

V času zatona protestantizma pa se je že leta 1597 odprla nova šola pri ljubljanskih jezuitih, ki je začela odtegovati učence stolni šoli. Zato je škof Hren jezuite povabil k sodelovanju v šoli sv. Nikolaja in tako zagotovil primerno število učencev. Med učitelji in pevovodji je iz druge polovice 16. stoletja in prve polovice 17. stoletja znanih kar nekaj imen (za mnoge izmed njih ni jasno, kdaj natančno so delovali, saj se v virih njihova imena ne pojavljajo redno): Abraham Kočevar, Sebastijan Samujen (1574-1576), Matija Feingast (1582-1585), Gregor Dorflinger (1588), Andrej Hren (1590-1591), Janez Plehan (1597, 1601), Nikolaj Treurer (1598), Matija Kolar (1606, 1608, 1611), Lenart Marius (1612-1613), Caharija Murmayr (1615-1616), Martin Caprarius (1617-1619), Martin Proj (1620-1621), Jurij Arnož (1621-1622), Matija Omerza (1625-1626), Filip Jakob Ithenus (1627) in Valentin Pistorius (1628-1656). Prav tako se je ohranilo kar nekaj imen pomočnikov: Gregorius (domnevno naj bi šlo za Dorflingerja; 1584), Gašper Maninger (1589), Gašper Hörbst (1606), Janez Novak (1606-1609), Jeremija Peinauer (1610), Matevž Fux (1613), Peter Ocepek (1617), Janez Planina (1618-1621), Valentin Pistorius (1621-1628) ter Marko Vicarri (1628-1629). Pomočniki so pogosto prihajali iz vrst stolniške nižje duhovščine, izobražene v gornjegrajskem kolegiju. Med učitelji pa so bili tudi gojenci graškega Ferdinandeuma, ki so sodelovali v tamkajšnji nadvojvodski glasbeni kapeli. ${ }^{24}$

Kaj so učenci pri bogoslužju v cerkvi sv. Nikolaja peli, ni mogoče z zagotovostjo reči. Domnevamo lahko, da so peli latinske liturgične koralne speve. Poleg tega bi lahko peli tudi pesmi, ki jih je Hren kot gradivo zbral za pesmarico, katere natis ni bil nikoli realiziran. ${ }^{25}$ Glede na to, da so po arhivskih virih sodeč prepevali večglasno glasbo, bi odgovor na vprašanje o repertoarju lahko ponudil inventarni popis zbirke muzikalij ljubljanske stolnice (Inventarium librorum musicalium ecclesiae cathedralis Labacensis), ki je nastal leta 1620 in se do ok. leta 1628 še dopolnjeval. ${ }^{26}$ Temu v prid govori tudi zaznamek

${ }^{22}$ Hren je veliko pozornosti namenjal tudi gornjegrajskemu kolegiju pri sostolnici v Gornjem Gradu, kjer je bila škofovska rezidenca. Pevci stolne šole so z gornjegrajsko kapelo večkrat sodelovali tudi že pred škofom Hrenom.

${ }^{23}$ J. Gruden, Šola pri sv. Nikolaju in ljubljansko nižje šolstvo po reformacijski dobi, str. 6-7.

${ }^{24} \mathrm{~J}$. Höfler, Glasbena umetnost pozne renesanse in baroka na Slovenskem, str. 8 in 22-24.

${ }^{25}$ Več o Hrenovem načrtu izdaje pesmarice gl. v delih: Janez Höfler, Nekaj novega o pesmarici Tomaža Hrena, Jezik in slovstvo 22/4 (1977); Edo Škulj, Škof Tomaž Hren in cerkvena glasba, Bogoslovni vestnik 52 (1992), str. 110-120.

${ }^{26}$ Več o inventarju v Dragotin Cvetko, Ein unbekanntes Inventarium musicalium aus dem Jahre 1620, Kirchenmusikalisches Jahrbuch 8 (1958), str. 77-80; J. Höfler, Glasbena umetnost pozne renesanse in baroka na Slovenskem , str. 36-41, zlasti pa prepis inventarja na str. 134-157; Metoda Kokole, The musical repertoire cultivated on the territory of modern Slovenia (1567-c. 1620) and its possible connections with the Court Chapel in Munich, Die Münchner Hofkapelle des 16. Jahrhunderts im europäischen Kontext. Bericht über das internationale Symposion der Musikhistorischen Kommission der Bayerischen Akademie der Wissenschaften in Verbindung 
»ad scholam Valentinus accepit«, za katerega Höfler meni, da se nanaša na Valentina Pistoriusa (kot je bilo že prikazano, je bil v letih 1621-1628 učiteljev pomočnik, od leta 1623 je poučeval figuralno glasbo, po letu 1628 pa je bil pevovodja). ${ }^{27}$

Popis navaja predvsem repertoar liturgične glasbe italijanskih skladateljev druge polovice 16. stoletja in začetka 17. stoletja. Med repertoarjem, navedenim v inventarju, so z glasbenoizobraževalnega stališča zanimive zlasti tri zbirke didaktične narave: Adriano Banchieri, L'organo suonarino (Benetke, 1605, 2. izdaja 1611, 3. izdaja 1622); Bernardino Bottazzi, Choro et organo [...] in cui con facil modo s'apprende in poco tempo un sicuro methodo per sonar su l'organo messe, antifone, \& hinni sopra ogni maniera di canto fermo (Benetke, 1614), ter po navedbah Höflerja tudi Giovanni Battista Rossi, Organo de cantori per intendere da se stesso ogni passo difficile che si trova nella musica, et anco per imparare contrapunto (Benetke, 1618). ${ }^{28}$ Prva navaja sistem osmih modusov in opisuje prakso liturgičnega orglanja, vsebuje pa tudi notni del ${ }^{29}$ druga opisuje dolžnosti pevovodje in organista pri bogoslužju ter vsebuje osnove kontrapunkta in še del z orgelskimi kompozicijami; ${ }^{30}$ tretja pa je namenjena samostojnemu učenju in podaja osnove kontrapunkta ter vsebuje prav tako glasbene primere (npr. Josquina in Palestrine). ${ }^{31}$ Vse so služile predvsem praktičnemu izobraževanju organistov, med katerimi bi lahko bili tudi organisti v ljubljanski stolnici.

Z glasbenega stališča je bil pomemben tudi leta 1597 novoustanovljeni jezuitski kolegij, ki je deloval vse do ukinitve jezuitskega reda leta $1773 .{ }^{32} \mathrm{~V}$ začetkih delovanja jezuitski kolegiji, ki so svojim gojencem nudili široko izobrazbo, na splošno niso namenjali posebne pozornosti glasbi, bila pa je vsekakor prisotna in postopoma je dobivala vse večji pomen. ${ }^{33}$ Splošni študijski red, ki je veljal za vse tovrstne jezuitske ustanove, je

mit der Gesellschaft für Bayerische Musikgeschichte, München, 2.-4. August 2004, ur. Theodor Göllner in Bernhold Schmid, München, Verlag der Bayerischen Akademie der Wissenschaften, 2006, str. 171-190; Metoda Kokole, From Graz to today's Central Slovenia: the influence of Italian polychoral music in the period c. 1595 to c. 1620, La musica policorale in Italia e nell'Europa centro-orientale fra Cinque e Seicento, ur. Aleksandra Patalas in Marina Toffetti, Benetke, Edizioni Fondazione Levi (v tisku).

27 J. Höfler, Glasbena umetnost pozne renesanse in baroka na Slovenskem, str. 37.

${ }^{28} \mathrm{~J}$. Höfler, Glasbena umetnost pozne renesanse in baroka na Slovenskem, str. 39.

${ }^{29}$ Prim. faksimilirano izdajo z uvodom Giulia Cattina: Adriano Banchieri, L'organo suonarino, Bibliotheca organologica 27, Amsterdam, Frits Knuf, 1969.

${ }^{30}$ Leo Schrade, "Choro e organo" di Bernardino Bottazzi, Rivista musicale italiana 36 (1929), str. 516-532.

${ }^{31}$ Tim Carter, Rossi, Giovanni Battista, Grove Music Online (1. oktober 2011).

${ }^{32}$ Dejavnost ljubljanskega jezuitskega kolegija osvetljujejo razprave v zborniku Jezuitski kolegij v Ljubljani (1597-1773). Zbornik razprav, ur. Vincenc Rajšp, Redovništvo na Slovenskem 4, Ljubljana, Zgodovinski inštitut ZRC SAZU, Provincialat slovenske province Družbe Jezusove, Inštitut za zgodovino Cerkve Teološke fakultete v Ljubljani, 1998. Vlogo glasbe v kolegiju prikazuje razprava Tomaža Faganela z naslovom Glasbeno delo v Ljubljanskem kolegiju: poskus prikaza ustroja in njegove vsebinske zasnove na straneh 229-233.

33 Splošni zgodovinski pregled delovanja jezuitskega reda v tem delu Evrope nudi Bernhard Duhr, Geschichte der Jesuiten in den Ländern deutscher Zunge, 4 zv., Freiburg im Breisgau [...], Herder, 1907-1928, pogled v glasbeno delovanje pa Max Wittwer, Musikpflege im Jesuitenorden unter besonderer Berücksichtigung der Länder deutscher Zunge, Greifswald, 1934 (Universität 
bil natisnjen leta 1599 v Rimu. ${ }^{34}$ Red določa naloge vzgojnoizobraževalnega procesa in izkazuje odlično organiziranost pouka, zaradi česar so bile jezuitske šole zelo priljubljene.

O dejanskem glasbenem življenju v začetku delovanja ljubljanskega kolegija moremo nekaj podrobnosti razbrati iz dveh ohranjenih jezuitskih kronik, prva je Historia annua Collegii Societatis Iesu Labacensis, ${ }^{35}$ druga pa Historia Seminarii Labacensis. ${ }^{36} \mathrm{Z}$ glasbo so se ukvarjali zlasti revni dijaki, združeni v posebni glasbeni seminar, ki je bil v kolegiju ustanovljen leta 1600 in je imel za zaščitnika sv. Rogacijana in Donacijana. Gojenci seminarja so tako kot v drugih izobraževalnih ustanovah, kjer so gojili glasbo, sodelovali pri obredju v cerkvi, in sicer tako s petjem kot tudi igranjem na instrumente. Eden izmed alumnatov, ustanovljenih za seminar, tako npr. predvideva organista iz vrst gojencev $;{ }^{37} \mathrm{v}$ letopisu Historia annua so tudi večkrat omenjeni instrumenti, na katere bi ti gojenci lahko igrali. ${ }^{38}$

Število dijakov v seminarju je z leti strmo naraščalo, z začetnih štirideset do osemdeset leta 1612 in preko sto leta 1617. Pri tem je treba vendarle poudariti, da se z glasbo mnogi gojenci niso ukvarjali. ${ }^{39}$ Repertoar, ki so ga gojenci izvajali, nam ni znan. Verjetno so med drugim peli slovenske pesmi, ki jih je škof Hren jezuitskemu učitelju Janezu Čandku predložil za izid v načrtovani pesmarici. ${ }^{40}$ Petje je spremljalo tudi igranje glasbil. ${ }^{41}$ Glasba v ljubljanskem kolegiju ni bila prisotna le pri cerkvenem obredju, temveč tudi na raznih prireditvah in šolskih igrah, toda na žalost o tovrstnih glasbenih dejavnostih v začetnem obdobju delovanja kolegija ni ohranjenih nikakršnih oprijemljivih podatkov.

Med drugimi izobraževalnimi institucijami, za katere vemo, da so gojile tudi glasbo, je še šola pri križevniški cerkvi, ${ }^{42}$ za katero od učiteljev in glasbenih vodij poznamo le Matijo Kolarja (omenjen v letih 1591 in 1594) in Gregorja Vidmarja (omenjen leta 1611). Znano je še, da so pevci šole pri cerkvi nemškega viteškega reda v Ljubljani 1. novembra

Greifswald, doktorska disertacija). Najnovejše študije o jezuitih in njihovem delovanju prinaša The Jesuits: cultures, sciences, and arts, 1540-1773, 2 zv., ur. John W. O'Malley, Gauvin Alexander Bailey, Steven J. Harris in T. Frank Kennedy, Toronto, Toronto University Press, 1999 in 2006.

${ }^{34}$ Ratio atque Institutio studiorum Societatis Jesu, Rim, In Collegio Societatis Jesu, 1599. Navedena izdaja predstavlja dokončno verzijo študijskega reda. Tej je kasneje sledilo še mnogo izdaj.

${ }^{35}$ Kronika je prevedena v slovenski jezik: Letopis Ljubljanskega kolegija Družbe Jezusove (1596-1691), prev. Marija Kiauta, Ljubljana, Družina, 2003.

${ }^{36}$ Gre za letopis ljubljanskega jezuitskega dijaškega doma. Pod signaturo Ms 156 ga hrani Rokopisni oddelek Narodne in univerzitetne knjižnice v Ljubljani (SI-Lnr, Ms 156).

${ }^{37}$ Janez Mlinar, Seminar za revne študente pri ljubljanskem kolegiju, Jezuitski kolegij v Ljubljani (1597-1773). Zbornik razprav, ur. Vincenc Rajšp, Redovništvo na Slovenskem 4, Ljubljana, Zgodovinski inštitut ZRC SAZU [...], 1998, str. 85.

${ }^{38}$ Leta 1610 je stiški opat kolegiju podaril regal, leta 1616 je baron Markvard pl. Egkh, komendator nemškega reda, podaril velike orgle, leta 1626 pa so omenjene nove orgle v cerkvi. Letopis Ljubljanskega kolegija, str. 66, 78 in 105.

${ }^{39}$ Höfler, Glasbena umetnost pozne renesanse in baroka na Slovenskem, str. 58.

${ }^{40}$ Gl. op. 25.

${ }^{41}$ Leta 1606 je v kroniki namreč zapisano: »Z ljubkim recitiranjem slovenskih pesmi in z različnimi napevi ob spremljavi glasbil so dečki na božični dan proslavili Dete Kristusa.« Letopis Ljubljanskega kolegija, str. 53.

42 Šola se sicer omenja že v 14. stoletju, vendar o njenem delovanju kaj več ni znanega. Gruden, Šola pri sv. Nikolaju in ljubljansko nižje šolstvo po reformacijski dobi, str. 3. 
leta 1598 sodelovali pri prvem ponovnem katoliškem bogoslužju v nekdanji protestantski špitalski cerkvi sv. Elizabete. Obredje je vodil škof Hren, ki je petje pri bogoslužju z naklonjenostjo omenil v svojem dnevniku. ${ }^{43}$

Čeprav na podlagi ohranjenega gradiva ni mogoče sestaviti popolne podobe glasbenoizobraževalnega dela v ljubljanskem šolstvu obravnavanega obdobja, saj ohranjeni podatki ne dopuščajo jasne slike o različnih vidikih glasbenega izobraževanja, je na podlagi stvarnih dokazov vendarle mogoče prepoznati nekatere njegove osnovne obrise. Ljubljana je bila na Kranjskem v tistem času najpomembnejše glasbenoizobraževalno središče. Osrednje nosilke glasbenega dela - zgoraj obravnavane institucije - so glasbeno usposabljale glasbenike, ki so delovali v večjih ali manjših glasbenih središčih na Slovenskem in prispevali h gojenju glasbene kulture. Glasbeni pouk je bil v vseh ustanovah usmerjen predvsem v prakso - učenje repertoarja, ki je bil v uporabi pri bogoslužju cerkve, v kateri so gojenci sodelovali. Sodelovanje pri bogoslužju je bilo eno izmed poglavitnih funkcij glasbenega izobraževanja tako v protestantskih kot katoliških šolah, čeprav se kaže, da so bile katoliške šole bolj neposredno vezane na cerkveno strukturo kot protestantske.

Zdi se, da je bilo v vseh omenjenih institucijah glasbenopedagoško delo usmerjeno predvsem v osnovno glasbeno usposabljanje. Najpomembnejše je bilo petje, ki so se ga gojenci na začetku učili s ponavljanjem za učiteljem (na pamet), kar kaže na to, da so začeli peti preden so se naučili brati, kasneje pa so lahko pridobili tudi znanje branja in pisanja not. O bolj zahtevnem teoretičnem pouku glasbe na podlagi virov ne moremo govoriti, kar pa še ne pomeni, da ga ni bilo.

Učenje instrumentov je bilo navadno prisotno izven institucionalnih okvirov, v privatnih krogih, in je bilo tudi bistveno manj razširjeno. ${ }^{44}$ Hkrati je to tudi razlog za odsotnost virov, ki bi razkrivali oprijemljive informacije o pouku instrumentalne igre. Položaj glasbenega izobraževanja se je v ljubljanskih izobraževalnih ustanovah v drugi polovici 16. in na začetku 17. stoletja, tako kot po večjem delu Evrope, pogosto spreminjal glede na dane okoliščine - včasih je bila glasba potisnjena na rob, drugič pa je zavzemala eno izmed pomembnejših mest.

${ }^{43}$ A. Rijavec, Glasbeno delo na Slovenskem v obdobju protestantizma, 1967, str. 10; J. Höfler, Glasbena umetnost pozne renesanse in baroka na Slovenskem, str. 26.

${ }^{44}$ James Haar, Some Introductory Remarks on Musical Pedagogy, Music Education in the Middle Ages and the Renaissance, ur. Russel E. Murray, Susan Forscher Weiss in Cynthia J. Cyrus, Bloomington in Indianapolis, Indiana University Press, 2010, str. 4. 


\title{
MUSIC EDUCATION IN SCHOOLS IN LJUBLJANA \\ IN THE SECOND HALF OF THE SIXTEENTH CENTURY \\ AND IN THE EARLY SEVENTEENTH CENTURY
}

\begin{abstract}
Summary
In Ljubljana, during the late sixteenth and early seventeenth century - a period marked by the rise of Protestantism, followed by Counter-Reformation (with its central figure, Tomaž Hren, Prince-Bishop of Ljubljana from 1597 to 1630) - music education is traceable mostly through an exploration of the musical activities at schools. The educational institutions of the period, which are the basis for our understanding of musical teaching and learning in Ljubljana, were the Protestant German and Latin schools, the cathedral school of St. Nicholas, the Jesuit college, and the school at the monastery of the Teutonic order.

Protestant German and Latin schools were the main formal institutions of learning during the second half of the sixteenth century. The goal of music education there was to prepare pupils for singing at church services in the reformed church of St. Elizabeth. Both schools were closed in 1598 by the proclamation of the sovereign's decree, which officially abolished Protestantism. Protestant teachers were consequently expelled from Ljubljana. At that time, Catholic schools once again began to gain their former importance. Both the scope and quality of the musical activities at the old cathedral school of St. Nicholas began to grow, providing the necessary liturgical music in the cathedral. Musical performances by the school choir are also attested to in the church of the Teutonic order. The situation at the Jesuit college, which was founded in 1597, where a special Music seminary was established, was similar. Unfortunately, musical activity at this college over its first decades is not documented very well.

This brief overview reveals the importance of schools' ecclesiastical connections, as students in every school were expected to participate at the church services with their singing. The main purpose of music education in the schools discussed was, therefore, to learn the musical repertory for the cultivation of music in the churches of Ljubljana.
\end{abstract}

